\title{
ИСПОЛЬЗОВАНИЕ МАЛЫХ СТИХОТВОРНЫХ ФОРМ (ЛИМЕРИКОВ) В ПРОЦЕССЕ ОБУЧЕНИЯ АНГЛИЙСКОМУ ЯЗЫКУ
}

\author{
О. В. Заеко, Т. А. Николаева \\ Московский гуманитарный университет
}

\begin{abstract}
Аннотация: В статье даётся определение лимерика, а также анализируются разные теории его происхождения, появления названия. Даются примеры переводов лимериков, показывается значимость использования лимерика в процессе обучения иностранномуязыку.
\end{abstract}

Ключевые слова: лимерик; фонетика; произношение; ударение; строка; юмор

\section{THE USE OF SHORT POEMS (LIMERICKS) IN THE PROCESS OF TEACHING ENGLISH}

\author{
O. V. Zaeko, T. A. Nikolaeva \\ Moscow University for the Humanities
}

\begin{abstract}
The article provides the definition of limerick and analyses various theories of its origin and name. The authors give examples of how limericks can be translated and demonstrate the possibility of using them in the process of teaching a foreign language.
\end{abstract}

Keywords: limerick; phonetics; pronunciation; stress; line; humour

Наш многолетний опыт работы на кафедре иностранных языков Московского гуманитарногоуниверситетапоказывает,что, ксожалению, общийуровеньвладения английским языком среди поступающих на 1 курс студентов с каждым годом неизменно снижается. Так, на сегодняшний день гораздо большее число студентов поступают в вуз с уровнем знания языка Beginner и Elementary. Соответственно и уровень произношения у этих студентов очень низкий. Преподаватели все чаще слышат вместо правильного произнесения определённого артикля the звук [h] внутри него, а слово bicycle получается похожим на [bikukle]. И таких примеров множество.

Чтобы «подтянуть» у студентов фонетику, преподавателям приходится в лучшем случае по 5 минут в начале занятия уделять фонетическим упражнениям, a в худшем случае начинать курс английского языка с фонетической транскрипции, правил чтения и произношения. Однако и такие меры, к сожалению, не всегда приносят результаты. Например, многие студенты до 3-го семестра продолжают делать неправильное ударение в слове hotel - не верно ставят ударение на первый слог.

На наш взгляд, существует весьма эффективный способ решить эту задачу, который применим при работе в том числе с инклюзивными студентами. Этот способ - использование лимериков. Согласно лаконичному определению толкового словаря "Longman Dictionary of Contemporary English": "Limerick is a humorous short poem that has five lines that rhyme" (Longman Dictionary ... , 2010: 1015). 
Как известно, лимерик - это форма короткого юмористического стихотворения, появившегося в Великобритании и основанного на обыгрывании какой-либо бессмыслицы. Традиционно в стихотворении должно быть 5 строк, построенных по модели AАВВА. Оригинальные лимерики сейчас можно найти на разных языках.

Лимерик помогает в усвоении английского языка студентами, так как знакомит их с особенностями произношения и правилами грамматики английского языка, а также с фольклорной традицией Великобритании, в связи с чем мы и обратились к изучению данной темы.

История происхождения лимерика доподлинно не установлена. Считается, что слово лимерик происходит от названия ирландского города Лимерика. Одна из версий связывает рождение лимерика с исполнением застольных песен, которые пелись когда-то в этом ирландском городе. Поначалу они были длинные, ихсочиняли на ходу в своеобразном поэтическом состязании. А потом, чтобы соревноваться в остроумии было проще, песни сократились до пяти строк и приобрели четкие правила.

Последующей версии названиестихотворения восходит кобычаюпридумывать и петь на вечеринках шуточные песенки, припевом которых была фраза «Will you come up to Limerick?» — «Вы приедете в Лимерик?»

Также существует гипотеза о том, что первые лимерики были не всегда приличными матросскими частушками, в них описывались самые невероятные и смешные случаи, произошедшие с матросами. Существует также предположение о том, что слово limerick происходит от ирландских слов a merry lay, означающих «веселая песня». Иногда это были некие «дразнилки», в которых высмеивались присутствующие (Маничкина, Рубцова, 2018). Таким образом, истоки жанра лимериков восходят к народному фольклору Великобритании.

Отдельного внимания заслуживают лимерики Эдварда Лира. Они возникли из игры с детьми, когда Эдвард Лир жил в поместье графа Дерби и развлекал своих маленьких друзей, рисуя для них нелепые рисунки и сочиняя к каждому рисунку такой же нелепый стишок.

Впоследствии Лир утверждал, что не надо искать никаких глубоких смыслов в его стишках - в них нет ничего, кроме чистейшей бессмыслицы. Популярность лимерик обрел после 1846 г., когда Лир издал две небольшие книжечки «A Book of Nonsense» и «More Nonsense» («Книга бессмыслиц» и «Еще бессмыслицы»). Всего Лир написал 212 лимериков, большинство из которых были забавно-абсурдного характера. В день его рождения, 12 мая - отмечается международный день лимериков.

Авторствомногихлимериковустановить практически невозможно.Существует мнение, что тяготение к лимерику связано с британским национальным характером.

Важно отметить, что в лимерике соблюдаются не только некоторые стихотворные, но и определённые сюжетные принципы. Так, в 1-й строке даётся информация о персонаже, кто он и откуда родом, во 2-й строке - сведения о том, что этот персонаж сделал, в остальных строках - информация о том, что из этого получилось. В классическом виде конец последней строчки лимерика повторяет конец первой.

Приведём пример известного лимерика Эдварда Лира 1872 г. и его перевода на русский язык (Лир, 2006: 81). 
There was a young person of Ayr,

Whose head was remarkably square:

On the top, in fine weather,

She wore a gold feather,

Which dazzled the people of Ayr.
Жила-была дама приятная,

На вид совершенно квадратная,

Кто бы с ней ни встречался,

От души восхищался:

«До чего ж эта дама приятная!»

Лимерик обычно начинается со слов «There was а...»

There was an Old Man of Peru,

Who dreamt he was eating his shoe.

He awoke in the night

In a terrible fright

And found it was perfectly true!
Однажды увидел чудак

Во сне, что он ест свой башмак

Он вмиг пробудился

И убедился,

Что это действительно так.

Герои лимериков - большие чудаки и чудачки, которые совершают различные неожиданные поступки, чем и привлекают внимание читателей.

\begin{tabular}{|l|l}
\hline There was a Young Lady of Niger, & Одна хохотушка-девица \\
Who smiled as she rode on a tiger; & Любила кататься на львице. \\
They returned from the ride & Признаться вам честно - \\
With the Lady inside, & Девица исчезла, \\
And the smile on the face of the tiger. & Зато улыбается львица.
\end{tabular}

Сюжетно лимерик может иметь два варианта.

Вариант 1

1 строчка - кто и откуда (пол и возраст, из местности),

2 строчка - какой? (обладает качеством),

3-4 строчка - которое проявляется как ...,

5 строчка - что вызывает реакцию людей...

There once was a man from Harare,

Who bought a brand new Ferrari.

Now the buck and the gnu

And the elephant too

Hide away when he goes on safari

Однажды африканец в Хараре

Купил себе новый «Феррари».

И теперь и олень и слоны

Все попрятались в кусты.

Так опустело сафари.

\section{Вариант 2}

1 строчка - кто и откуда? (пол, возраст, из местности),

2 строчка - что сделал? (совершает поступок),

3-4 строчка - что из этого получилось? (который приводит к последствиям),

5 строчка - реакция на этот поступок, обычно конец последней строки повторяет конец первой.

\begin{tabular}{|l|l|}
\hline There was an Old Person of Dundalk, & Некий мистер из города Далсем \\
Who tried to teach fishes to walk; & Научить рыб ходьбе все пытался; \\
When they tumbled down dead, & Но, не сдавши экзамена, \\
He grew weary, and said, & Рыбы падали замертво, \\
'I had better go back to Dundalk!' & А учитель, вздыхая, шел в Далсем. \\
\hline
\end{tabular}

Отдельного внимания заслуживает такой вид работы над лимериком, как перевод. Лимерики переводились и переводятся на многие языки мира. Прекрасные переводы выполнены С. Маршаком. Широко известны переводы К. Чуковского. 
Благодаря переводам С. Маршака и К. Чуковского, дети Советского Союза познакомились с Робином Бобином, с Джеком, который построил дом и многими другими. Позднее многие авторы обращались к переводам лимериков на русский язык.

Секрет перевода состоит в том, чтобы сохранить рифму, стихотворный размер лимерика, а также не потерять его юмористический характер. Переводчикам нередко приходится менять географию лимерика и собственные имена героев, жертвовать второстепенными деталями, либо заменять их, чтобы сохранить поэтическую форму и каламбур произведения.

Для того, чтобы использовать эти забавные «частушки» для разучивания новых английских слов, точный стихотворный перевод не нужен. Форма лимерика позволяет выучить стих «нараспев», новые слова пополняют активный запас, а забавный сюжет не нуждается в дополнительном заключении в стихотворную форму на родном языке. Например, хорошей тренировкой гласных звуков и дифтонгов может стать прочтение вслух и последующее заучивание следующего лимерика.

There was an Old Man with an owl,

Who continued to bother and howl;

He sat on a rail

And imbibed bitter ale,

Which refreshed that Old Man and his owl.

В ходе написания статьи нами была предпринята попытка самостоятельного сочинения лимериков.

There was a man named Derek

Who usually was in hysterics.

Every time he saw mice

They made him faint twice.

This scaredy cat named Derek.

На наш взгляд, на основе этого лимерика можно изучить или повторить правила употребления прошедшего времени глагола to be, познакомиться с новыми лексическими единицами, глаголом faint и выражением scaredy cat, повторить правила образования множественного числа существительных и в том числе исключений, к которым относится слово тісе, изучить правильное правописание слова hysterics.

Также можно предложить студентам на занятии в парах или группах сочинить небольшие четверостишия по последней пройденной лексической теме. Данный творческий процесс вполне может вдохновить их к дальнейшей работе над лимериком, будет способствовать запоминанию ими грамматических конструкций, звуков и активной лексики урока.

Например, на основе следующего лимерика можно тренировать у студентов произношение слов, заканчивающихся на-ing (shillings, feelings), чтение удвоенных согласных (Kilkenny, penny).

There was a beggarly man of Kilkenny,

Who asked near a church for a penny.

But when he showed his feelings

He was given two shillings.

Such an artistic old man of Kilkenny.

На основе нижеследующего лимерика можно закрепить употребление прошедшего времени (формы loved, was, didn't), познакомить студентов с географическим названием Chelsea, именем собственным Elsie. 
There was a young man from Chelsea

Who loved a girl named Elsie

But he was so shy

That he didn't ever try

To open his heart to Elsie.

В следующем лимерике читатель знакомится с еще одним географическим названием Bristol, чередованием звуков в похожих по звучанию словах fun, began.

There was a young man of Bristol

Who wanted to fire a pistol.

He thought it was fun,

But when he began

He was taken to prison in Bristol.

Следующий лимерик построен на игре слов: пари bet и имени Bet.

There was a girl whom we called Bet.

Because we couldn't forget

How she swallowed a cockroach

On a bet with her coach.

So we shortened name Betsy to Bet.

Ещё один лимерик нашего сочинения тренирует правильное произношение буквосочетания "wh" в вопросительных словах why, who, when, where. Преподаватель, предложив студентам данный лимерик, может попросить их самостоятельно сделать вывод о произношении вопросительных слов. Предполагается, что студенты должны самостоятельно понять, что, если после буквосочетания "wh" следует буква "o" (в слове who - кто?), то буква «w» не читается и произносится звук [h]. Во всех остальных случаях вопросительные слова начинаются со звука [w], например, слова why, where, when.

It plays a great role

To say correctly who and whole.

But to continue this plot

We always say why, where, when and what.

And you, such a clever guy, can you tell me why?

Наконец, поработав со студентами над чтением и переводом нескольких готовых лимериков, можно предложить им самостоятельно закончить сочинение лимерика, где предложены только две начальные строки.

There was a young girl named Lilly

She was pretty but awfully silly...

На наш взгляд, очевидная польза активного применения лимерика в учебной аудитории для тренировки навыков произношения заключается прежде всего в том, что, так как в лимерике соблюдаются определённый стихотворный размер, ритм, фразовое ударение, то неправильное произнесение слов в связи с несоблюдением изложенных норм приводит к нарушению рифмы и весь смысл стихотворения при этом теряется. А если стихотворение прочитано правильно, то запоминается и правильное произношение и написание слов. Таким образом достигается задача усвоения новой лексики и правильного произнесения слов.

Что касается грамматики, то лимерик даёт возможность запомнить грамматические правила на конкретных примерах их употребления, а незнакомые слова, встречающиеся в тексте стиха, могут мотивировать студентов воспользоваться словарём, что в свою очередь обогатит их словарный запас. 


\section{СПИСОК ЛИТЕРАТУРЫ}

Лир, Э. (2006) Книга бессмыслицы М.: АСТ, Восток-Запад. 128 с.

Маничкина, А. М., Рубцова, А. В. (2018) Лимерик как жанр фольклорной поэзии Англии // Старт в науке. № 4-1. С. 53-58.

Longman Dictionary of Contemporary English. (2010). New edition. Edinburgh : Pearson Longman. 2224 p.

Дата поступления: 10.05.2020 2.

Заеко Ольга Вадимовна - доцент кафедры иностранных языков Московского гуманитарного университета. Адрес: 111395, Россия, г. Москва, ул. Юности, д. 5. Тел.: +7 (499) 374-75-92. Эл. адрес: romanyk_vit@mail.ru

Николаева Татьяна Андреевна - доцент кафедры иностранных языков Московского гуманитарного университета. Адрес: 111395 , Россия, г. Москва, ул. Юности, д. 5. Тел.: +7 (499) 374-75-92. Эл. адрес: t.nikolaeva@list.ru

Zaeko Olga Vadimovna, Associate Professor, Department of Foreign Languages, Moscow University for the Humanities. Postal address: 5, Yunosti St., Moscow, Russian Federation, 111395. Tel.: +7 (499) 374-75-92. E-mail: romanyk_vit@mail.ru

Nikolaeva Tatyana Andreevna, Associate Professor, Department of Foreign Languages, Moscow University for the Humanities. Postal address: 5, Yunosti St., Moscow, Russian Federation, 111395. Tel.: +7 (499) 374-75-92. E-mail: t.nikolaeva@list.ru

\section{Для цитирования:}

Николаева Т. Н., Заеко О. В. Использование малых стихотворных форм (лимериков) в процессе обучения английскому языку // Научные труды Московского гуманитарного университета. 2020. №3. C. 19-24. DOI: https://www.doi.org/10.17805/trudy.2020.3.4 